\title{
The Impact of Pre and Post Homework Assignments on the Ninth Grade Students' Achievement in Islamic Education
}

\author{
Ahmad Mohidein Kilani ${ }^{1, *}$ \\ ${ }^{1}$ Department of Education Sciences, World Islamic Sciences \& Education, Amman, Jordan \\ *Correspondence: Department of Education Sciences, World Islamic Sciences \& Education, \\ P.O box 003, Amman, Jordan. E-mail: hash_mored@yahoo.co
}

Received: September 17, 2014 Accepted: November 27, 2014 Published: March 23, 2015

doi:10.5296/ije.v7i1.6323 URL: http://dx.doi.org/10.5296/ije.v7i1.6323

\begin{abstract}
This study aimed at identifying the effect of the pre and post homework in the ninth grade students' achievement in Islamic Education subject. And to achieve this objective, three sections of ninth grade students in Nadeem Al-Malah Basic School for Boys were selected and divided into three groups; two experimental groups where one of them is given pre homework while the other is given post homework and the control group is not given any homework. An achievement test was applied on the groups. The study came up with the following results: the two experimental groups (the pre-homework and the post-homework) showed superiority over the control group in the achievement test. And the group of post-homework showed superiority over the experimental group of pre-homework. The study recommended the teachers' adaptation of the post-homework and variance of periods of time for addressing these homework.
\end{abstract}

Keywords: Islamic education, homework, ninth grade 


\section{Introduction}

Homework is considered one of the most important activities which is given to the students in the class to check the students' degree of learning and their mastering of the concepts, and to promote their learning (Al-Shara\&Abed, 2008). Abdrahim(1996) pointed out that homework is the school's effective activity done by the students outside the school according to the teacher's request and his guidance for the preparation of the new lesson or a specific subject. Homework achieves many goals as linking the new experience with the previous one, paying attention to the students' individual differences, attracting the students' interest towards the lesson and achieving independency, responsibility and self guidance(Faraj, 1997 \& Zeitoon, 1998). Homework is based on a set of standards: it has to be planned and assigned regularly and its objectives should be clear and specified, it should also motivate the students and attract their attention (Posamentier \& Stepelmen, 1986). Homework has specific requirements as linking the topic of the homework with the students' experiences, motivating the students, identifying the nature of their cognitive content and the students' quality in terms of their interests, in addition to the students' interests in doing them(Al-Ajami,1991). Although of the positive effects of the homework, it has negative effects as well. For example, the students feel bored and the principle of Individual Learning is not achieved because the teachers are not aware of the characteristics of the homework.

Kralovec \& Buell(2001) believe that the homework does not reveal the students' real level of learning and even it does not allow the students to practice their hobbies and sometimes homework is considered waste of time and effort. The researcher believes that it is possible to avoid the negative sides of the homework if it was chosen according to specific and clear basis taking into account the students' interests. Moreover, homework should be appropriate in time and varied in its topics. Therefore, about the homework' importance, many studies addressed this topic from different sides; some studies discussed students' attitudes towards homework while other studies addressed the impact of the homework on the students' achievement and motivation. Shabib's study(1995)aimed to identify the level of the achievement in Arabic Grammar of the students who were asked to do some homework in general and it also aimed to identify the students' level of achievement who did their preparation homework compared with the students' level who were assigned to do training homework. The sample of the study consisted of 535 male and female students of ninth basic grade in UNRWA schools in the Southern Area of Amman. The results revealed the superiority of the groups which were assigned to do the preparation and training over the group which was assigned to do general homework in the achievement.

While Rshid's study(1991) aimed at identifying the teachers' and the seventh, eighth and ninth grade students' attitudes towards the homework in Arabic in the public schools of Irbid city. The sample of the study consisted of 111 male and female teachers and 626 male and female students. The results showed that the teachers' and the students' attitudes were positive. Similarly, Harris, et al( 1991) conducted a study aimed at examining the students' views towards the homework 57 male and female students of the $11^{\text {th }}$ grade in the public schools in Britain were interviewed. The results showed that females tend to organize the time of implementing the homework better than the males who showed less commitment than 
the females to implement the homework in the last moments or they do not. And the study of Cooper, et al (2001)addressed the effect of the homework in the class's performance of the basic stage's students and the relation of the parent's attitudes towards homework with the relation of their children towards them. The sample of the study consisted of 28 teachers and 428 students in addition to 428 parents. The results showed lack of relation between the students' attitudes towards the homework and their classroom's grades, the results also showed the parents' attitudes towards the homework affect their children attitudes towards the homework. According the effect of homework in achievement, Rahal (2001) conducted a study to identify the best strategies to evaluate the homework in terms of its influence in the students' achievement and their retention of the information and these strategies are: not evaluating the homework, teacher's signature on the homework and grading the homework. The sample of the study consisted of 117 male and female students of the ninth grade in UNRWA schools in Nablis city. The study concluded that the best strategy in evaluating the homework, improving the students' achievement and enhancing students' retention of the information was the strategy of grading the homework.

In the same context, Al-Enizi(2002) conducted a study to examine the impact of using a proposed program in following up the homework in the fifth grade students' achievement in Mathematics. The sample of the study consisted of 56 male students of the fifth grade in one of the Saudi schools. The results showed an impact of using the proposed program in following up the homework in the students' achievement. According to surveying studies, Abo Awad(2002) conducted a survey study to evaluate the homework used by the teachers of basic stage in Amman Great Area. And the sample of the study consisted of 720 male and female students and 260 male and female teachers in addition to 270 parents. The results revealed that homework used by the teacher were interested in the low levels of the cognitive objectives and they are implemented individually and do not encourage the cooperative learning. And the results showed that teachers, parents and the students agreed on the importance of homework in increasing achievement and strengthening learning and self confidence. Abdrahman(2011)also conducted a study to identify the effect of using homework in the basic fourth grade students' achievement in Arabic at the schools of Tlkarm. The sample of the study, which consisted of 130 male and female students, was distributed to experimental and control group; the experimental group taught using the homework while the control group taught without using the homework. The results revealed an effect to the homework in increasing the achievement in favour of the experimental group in Arabic.

The closest study to the current study in terms of its objectives and methodology is Al-Hasanat's study(2013) which aimed at identifying the impact of homework diversity in terms of time in improving levels of reading comprehension and writing skills in Arabic among the tenth grade students. The study was applied on 176 male and female students distributed into four groups; three experimental groups and one control group. The first experimental group was given pre homework, the second one was given post homework while the third one was given pre and post homework. The control group was not given any homework. The results concluded to the superiority of the three experimental groups in improving the levels of reading comprehension and writing skills and the first group with the 
pre homework showed superiority over the other two experimental groups.

It is clear from the previous studies that the homework has an impact and efficiency in improving the educational outputs in general and the cognitive achievement in particular. It can also be noticed that lack of studies addressed the impact of homework in the field of Islamic Educaion although of its importance and relation in this field. So this study tries to reveal the impact of the pre and the post homework on the ninth basic grade students 'achievement in Islamic Education subject.

\subsection{Problem of the study}

The homework has a major role in the classroom's situation as it provides the students with feedback about their academic achievement and it also prepares the educational situation which in turn improves the educational outputs and this was asserted by the previous studies which were addressed in the educational field in general.

But this role of homework has not been discussed and addressed in the field of Islamic Education for the lack of the researches and studies in addition to the variety of the pre or post homework which were not discussed scientifically except the study of Al-Hasanat(2013) which was mentioned previously and therefore, the best and the appropriate times to give the students the homework has not been known yet. This current situation motivates the researcher to conduct this study to identify the impact of pre and post homework assignments on the ninth grade students' achievement in Islamic Education.

\subsection{Questions of the study}

The study answered the following questions:

What is the impact of the pre homework on the ninth grade students' achievement in Islamic Education subject compared with the traditional method(without giving any homework assignment)?

What is the impact of the post homework on the ninth grade students' achievement in Islamic Education subject compared with the traditional method(without giving any homework )?

Are there any statistically significant differences in the ninth grade students' achievement attributed to the pre and post homework?

\subsection{Significance of the study}

The significance of this study is represented by the following:

This study relates to the students' learning process in an important and critical level of students' school education which is the basic ninth grade.

The study presents a perspective of the best and appropriate time for giving the students the homework in order to increase their cognitive achievement.

This study may help the teachers of Islamic Education concerning the importance of giving pre or post homework. 


\section{Macrothink}

The study presents a feed back to the authors of the Islamic education books about the time of presenting the homework to the students in light of the results of this study.

\subsection{Procedural definitions}

The researcher defines the following expressions procedurally:

Homework: they are a set of educational activities regarding the content of a specific lesson in the school unit (Figh) of Islamic Education's book of the basic ninth grade whether they were before or after the lesson.

Achievement: the response of the sample of the study towards the achievement test's items which was prepared by the researcher.

Basic ninth grade students: the students who study regularly in the government schools which belongs to the Directorate of Wadi Mosa in the first semester for the academic year2013-2014.

\subsection{Limitations of the study}

The study was limited to the following limitations:

- Ninth grade students in Nadeem Malah Basic School for Boys of Wadi Mosa Directorate of Education.

- $\quad$ The study was conducted in the first semester of the year 2013-2014.

- The study addressed the unit of "Figh" from the ninth grade's Islamic Education book.

- The results of the study can be generalized in light of the study's tool's validity and the objectivity of the respondents of it.

\section{Method}

This part of the study includes the description of the approach which the study followed, the sample of the study and their distribution into the groups of the study in addition it addresses the tool of the study and its validity and reliability, procedures of the study and its variables and the statistical treatment.

\subsection{Approach of the study}

The study followed the quasi- experimental approach of two experimental groups and one control group.

\subsection{Members of the study}

The members of the study are the basic ninth grade students in Nadeem Al-Malah Basic School for Boys at Wadi Mosa Directorate of Education in Amman and they are 89 students distributed into three groups randomly, and (Table 1) illustrates this. 
Table 1. Distribution of the Members of the Study into Three Groups

\begin{tabular}{lc}
\hline Group & N \\
\hline First experimental group ( pre homework assignment) & 31 \\
First experimental group ( post homework assignment) & 31 \\
Control group ( without homework assignments) & 27 \\
Total & 89 \\
\hline
\end{tabular}

\subsection{Tool of the study}

The researcher built a achievement test based on the unit of Figh from the Islamic Education book of the basic ninth grade after he had analyzed the unit and prepared the table of test descriptions. And the initial copy of the test consisted of 20 multiple-choice items measures he cognitive levels according to Bloom's classification (Knowledge. Comprehension. Application. Analysis. Synthesis. Evaluation).

\subsection{The test's validity}

To check the test's validity, Face Validity was adopted by displaying the test on a group of experts and specialized who represent Jordanian academic staff's members and the teacher of Islamic Education. The arbitrators' notices were taken into account; three items were adjusted linguistically $(5,12,17)$ and substitutes (answers) of two questions were adjusted (18.19).But no item was deleted and so the final copy of the test consisted of 20 items.

Coefficient of difficultly and discrimination of the achievement test's items

The researcher found out the indexes of difficulty and discrimination of the achievement test's items, and Table 2. illustrates this.

Table 2. Coefficient of Difficulty and Discriminate of the Achievement Test's Items

\begin{tabular}{lll}
\hline $\mathrm{N}$ of item & Difficulty Coefficient & Discrimination Coefficient \\
\hline 1 & 0.50 & 0.58 \\
2 & 0.48 & 0.37 \\
3 & 0.47 & 0.33 \\
4 & 0.50 & 0.47 \\
5 & 0.49 & 0.41 \\
6 & 0.44 & 0.27 \\
7 & 0.49 & 0.40 \\
8 & 0.50 & 0.41 \\
9 & 0.46 & 0.36 \\
10 & 0.49 & 0.31 \\
11 & 0.49 & 0.37 \\
12 & 0.49 & 0.42 \\
13 & 0.47 & 0.52 \\
14 & 0.50 & 0.67 \\
\hline
\end{tabular}




\begin{tabular}{lll}
\hline 15 & 0.48 & 0.24 \\
16 & 0.48 & 0.27 \\
17 & 0.46 & 0.44 \\
18 & 0.50 & 0.32 \\
19 & 0.86 & 0.31 \\
20 & 0.44 & 0.48 \\
\hline
\end{tabular}

\subsection{Test's reliability}

The test's reliability was checked by applying Test and Retest Method on a sample of basic ninth grade students which consisted of 35 students out of the sample of the study. And after two weeks, the test was repeated. The Pearson correlation coefficient was $(0.82)$.

\subsection{Variables of the study}

The study includes Independent variables and a dependent variable.

The Independent Variables: homework assignments and have three levels:

- Pre homework assignments

- Post homework assignments

- Without any homework assignment.

The dependent variable: the basic Ninth grade students' achievement

\subsection{Procedures of the study}

To achieve the objectives of the study and answer its questions, the researcher did the following:

- Selected the members of the study from the basic ninth grade students of Nadeem Malah basic school for boys.

- Trained the teacher of Islamic Education on the procedures of implementing the lessons according to the variety of homework assignments whether they were pre or post the unit of Figh from the ninth grade's book of Islamic Education.

- Constructed a multiple - choice achievement test and checking its validity and reliability.

- Carried out a pre -achievement test to make sure of the equivalence of the groups of the study and the results were recorded and the means were calculated for every group.

- Provided the teacher with the pre and post homework assignments of the unit of Figh which was selected from the Islamic Education subject of the basic ninth grade.

After finishing teaching the educational unit directly, the post -achievement test was applied on the groups of the study. The students' answers on the achievement test were corrected and 
the results were recorded by the teacher. Then the researcher made the necessary statistical treatments and came up with some results, discussions and interpretations of these results and presented some recommendations.

\subsection{Statistical treatments}

To answer the questions of the study, means and standard deviations were calculated and the Analysis of Covariance (ANCOVA) and Scheffe' Test for Post Hoc Comparisons were used to identify the differences between the means of the performance of the members of the sample.

\section{Results}

In this part, the results are addressed and discussed according the questions of the study as follows:

First Question: What is the impact of the pre homework on the ninth grade students' achievement in Islamic Education subject compared with the traditional method(without giving any homework assignments)?

Second question: What is the impact of the post homework assignments on the ninth grade students' achievement in Islamic Education subject compared with the traditional method(without giving any homework)?

Third question: Are there any statistically significant differences in the ninth grade students' achievement attributed to the pre and post homework?

To answer these questions, means and standard deviations of the performance of the members of the study on the achievement test according to homework variable were calculated, and table 3 illustrates this.

Table 3. Means and standard deviations of the performance of the members of the study on the achievement test according to homework variable

\begin{tabular}{llllll}
\hline Homework & N & $\begin{array}{l}\text { Pre-test } \\
\text { Mean }\end{array}$ & Std & $\begin{array}{l}\text { Post-test } \\
\text { Mean }\end{array}$ & Std \\
\hline Pre-homework & 31 & 11.97 & 3.27 & 16.16 & 2.75 \\
Post-homework & 31 & 13.52 & 3.36 & 17.00 & 1.46 \\
Traditional & 27 & 10.04 & 3.37 & 10.81 & 4.08 \\
Total & 89 & 11.92 & 3.58 & 14.83 & 3.93 \\
\hline
\end{tabular}

It is clear from table (3), that the mean of the performance of the members of the study on the post- achievement test and who were given pre-homework was (16016)and the mean of the performance of the members of the study on the post- achievement test and who were given post-homework was(17.00) and the mean of the members of the study who were taught traditionally (without homework ) was (14.53). And to know if the differences between the 
means were statistically significant at the level of significance $(a=0.05)$, the Analysis of Covariance (ANCOVA) was used, and table 4 illustrates this.

Table 4. Results of Analysis of Covariance (ANCOVA) of the study's members' performance on the achievement test according homework variable

\begin{tabular}{llllll}
\hline $\begin{array}{l}\text { Source of } \\
\text { variance }\end{array}$ & Sum of seq. & Df & $\begin{array}{l}\text { Mean squares } \\
(\mathrm{MS})\end{array}$ & F value & Sig. \\
\hline Pre-test & 1.707 & 1 & 1.707 & 0.201 & 0.655 \\
Homework & 527 & 2 & 263.5 & 31.08 & $* 0.000$ \\
Error & 720.6 & 85 & 8.477 & & \\
Total & 1358 & 88 & & & \\
\hline
\end{tabular}

It is clear from the previous table that $(\mathrm{F})$ value according to the homework was (31.09) with a significance (0.00o) which indicates that there are statistically significant differences between the means of the performance of the members of the study on the post-achievement test .And the adjusted means were calculated as they are clear in table 5 .

Table 5. The adjusted Means and the standard deviation of the performance of sample's members on the achievement test according to homework assignments

\begin{tabular}{llll}
\hline Homework & N & Mean & Standard Error \\
\hline Pre-homework & 31 & 16.16 & 0.52 \\
post-homework & 31 & 16.93 & 0.54 \\
Traditional (without homework) & 27 & 10.90 & 0.59 \\
Total & 89 & 14.66 & 0.31 \\
\hline
\end{tabular}

It is noted from the previous table that the adjusted mean of the sample's members' performance on the achievement test and who were given pre-homework was (16.16) while the adjusted mean of those who were given post-homework was (16.93). And to know the significance of these differences, Scheffe' Test Post Hoc Comparisons, and table (6) illustrates this.

Table 6. Results of Scheffe' Test for the differences between the means of the members of the sample's performance on the achievement test according the homework variable

\begin{tabular}{lllll}
\hline \multirow{2}{*}{ Homework } & Mean & $\begin{array}{l}\text { Pre- } \\
\text { homework }\end{array}$ & $\begin{array}{l}\text { post- } \\
\text { homework }\end{array}$ & $\begin{array}{l}\text { Without } \\
\text { homework }\end{array}$ \\
\cline { 3 - 5 } & & 16.16 & 16.93 & 10.90 \\
\hline Pre- homework & 16.16 & - & 0.77 & $* 6.03$ \\
post- homework & 16.93 & & - & $* 5.26$ \\
Without homework & 10.90 & & & - \\
\hline
\end{tabular}

The previous table shows clearly the following:

First: The difference was in favor to the experimental group which was given post homework when their mean was compared to the mean of the control group(without 
homework assignments), and this may due to the idea that homework are considered an opportunity to the students to learn individually and they provide them with varied educational experiences as they are described as one of the important models in the process of education and learning(Saeda \& Ibrahim, 1997).

And this result may attributed to the fact that homework consolidate information in the students' minds and teach them the real and organized work in addition to teach them the independent continuous thinking (Fayd,1974). And this result agreed with the results of many studies by (Shabib, 1990; Cooper, et.al, 2001; Al-Enzi, 2002; Abd-Rhman, 2011 and Al-Hasanat, 2013)

Second: the difference was in favor of the experimental group, which was given pre homework assignments, when its mean was compared with the mean of the control group(without homework). And this result may due to the role of the pre homework in motivating the students and increasing their furious towards the educational course before it has been explained by the teacher and this was assured by the study of Al-Hasanat(2013). Giving the students pre homework, it means that students can take an idea about the concepts mentioned in the lesson in comparison with their classmate who were not given pre homework. This result asserted the importance of homework and its role in increasing the achievement and the educational literature agreed on this importance as Ruppert, 1999; Brook hart, 1995). The result agreed with the results of the following studies: Cooper, et. al., 2001; Al-Enzi, 2002; Abdrahman, 2011; Al-Hasanat, 2013.

Third: there were differences between the mean of the experimental group and the mean of control group in favor of the experimental group which was given pre homework.

This result may attribute to the students' cognitive experience that includes acquiring the concepts mentioned in the lesson followed by the teacher's explanation of these concepts, principals and different types of evaluation. Then the students were assigned to do the homework. And this experience supplied the students with regulations and guidance to do post homework compared with the group which were assigned to do pre homework. The group of pre homework did their homework without having the opportunity to know the topic of the lesson correctly. This result was in disagreement with the result of Al-Hasanat's study(2013) which showed the superiority of the group which was given pre homework over the group which was given post homework in achievement.

\section{Recommendations}

In light of the results, the study recommended the following:

- To activate the homework assignments in the subject of Islamic Education for their impact on the students' achievement.

- To vary the time of giving the homework assignments whether they were pre or post ones. 
- To diversify the time of giving the pre or the post homework.

- To pay attention to the post homework assignments which are prepared according to appropriate scientific bases.

- To conduct further studies which are similar to this studies to identify the impact of the pre and post homework on the students' motivation towards learning.

\section{References}

Abdrahim, A, H. (1996). Project of implementing the school assignments to the 1st and 2nd elementary grades inside the classroom under the school's supervision. Bulletin of the Faculty of Education, University of Qatar, N68 p121-152.

Abdrahman, S. (2011). Impact of homework on the achievement of the staduents of basic stage in Tolkarm Governorate, Unpublished Thesis, An-Najah National University, Nabils, Palestine.

Abo-Awad, F. (2002). .Evaluating the homework assignments that the teachers use in the basic education stage in great Amman area. Unpublished Thesis, University of Jordan, Amman, Jordan.

Al-enzi, M. (2002). Impact of following up homework on the fifth grade students' achievement in Math. University of Jordan, Amman, Jordan.

Al-Hasanat, H, A. (2011). Effect Of Homework's Diversity In Term Of Time In Improving Levels Of Reading Comprehension And The Skills Of Writing Of The 10th Grade Students. Dissertation, International And Islamic Sciences University, Amman, Jordan.

AL-Shar', I \& Ayid, O. (2008). The students' attitudes towards homework in schools of Amman. An-Najah University Journal for Research - Humanities, 22(3), 702-725.

Brook hart, S. (1995). Effect of the classroom assessment Environment on the Achievement in mathematics and science, (Paper Present at the annual meeting PF the American Educational Research Association), Sanfrancisco.

Cooper, H., Jackson, K., Barbara, N., \& James, J. (2001). A model of homework's influence on the performance evaluations of elementary school students. Journal of Experimental Education, 69(2), 181-200. http://dx.doi.org/10.1080/00220970109600655

Farah, A. (1990). School homework in the secondary school from the students' perspective. Journal of Education College, 42(5), 112-145.

Fayd, A. (1974). Pioneer of education \&teaching foundations. Beirut, Lebanese Dar Elkita.

Harris, S., Nixon, J., \& Rubbuck, J. (1991). School work, Homework and Gender. Gender and Education, 5(1).

Kralovec, E., \& Buell, J. (2001). End homework now. Educational leadership, 58(7), 39-42. 


\section{Macrothink}

International Journal of Education

ISSN 1948-5476

2015, Vol. 7, No. 1

Posamentier, A., \& Stepleman, J. (1986). Teaching Secondary School Mathematics. London Charles E. Merrill Publishing Company, 54-57.

Rahal, A. (2001). Impact of three strategies of evaluating homework on achievement and retention of the Statistics Subject in Math among the ninth grade students in the schools of UNWRA in Nablis. Unpublished Thesis, An-Najah National University, Nablis, Palestine.

Rashid, K. (1991). Attitudes of Teachers and the students of 7th, 8th and 8t grade students from the basic stage towards the homework assignments in Arabic and the problems hinder the performance of these homework. Unpublished Thesis, Yarmouk University, Irbid, Jordan.

Ruppert, M. (1991). The Effects of two goal setting procedures on math performance (multiple baseline). University of Nebraska- Lonco in Degree: PHD, DAI-A 60/60. P. 77.

Sa`da, Jt \& Ibrahim, A. (1997). School curricula in the first century. Kuwait, Al-Flah library.

Shabib, Kh. (1990). Impact of the preparation and training homework on the ninth grade students' achievement in Arabic Syntax. Unpublished Thesis, University of Jordan, Amman, Jordan.

Zeiton, K. (1998). Teaching: its models and skills.ed2, Alexandria, Al-Alami Office for computer publishing and distribution.

\section{Copyright Disclaimer}

Copyright for this article is retained by the author(s), with first publication rights granted to the journal.

This is an open-access article distributed under the terms and conditions of the Creative Commons Attribution license (http://creativecommons.org/licenses/by/3.0/). 